International Journal of English Literature and Social Sciences
Vol-6, Issue-5; Sep-Oct, 2021
Journal Home Page Available: $\underline{\text { https://ijels.com/ }}$ Journal DOI: $10.22161 /$ ijels

Peer-Reviewed Journal

\title{
Ted Hughes and his poetry
}

\author{
Dr. N. M. Shah
}

Associate professor, Department of English, Monad University, Uttar Pradesh, India

Received: 02 Sep 2021; Received in revised form: 25 Sep 2021; Accepted: 02 Oct 2021; Available online: 08 Oct 2021

(C)2021 The Author(s). Published by Infogain Publication. This is an open access article under the CC BY license

(https://creativecommons.org/licenses/by/4.0/).

\begin{abstract}
This paper attempts to explain the power of Men and Animal in Ted Hughes' poetry, and find out a particular vision and modern concept of Ted Hughes. Hughes's poetry bears a stamp of originality and a particular observation, an expression of his own in it. Ted Hughes's poetic mission has always been to open our eyes to the power and mystery of the universe we inhabit. The article analysis the poetry of Ted Hughes that reflects man enlightenment from animals.
\end{abstract}

Keywords - Ted Hughes, Ted Hughes' poetry, animal poetry, Men and animals.

\section{INTRODUCTION}

Poetry is the most important branch of literature without which no literature in the world can claim itself to be perfect. Poetry is the expressions of the emotional aspect of the poet's personality, through which a poet unlocks his mind and lets others, know a lot of things about him. Poetry has always performed an incredible task in world literature.

Wordsworth also accepts the value of the poetry in the life of man. Indeed, he is right for poetry succeeds in revealing even the most secret feelings of man that are hardly known to others. The purpose of poetry is to impart delight. The most remarkable quality of poetry is that it can raise and quell every emotion of man. Poetry is communication. The poet is supposed both to instruct and delight. Serious poetry provides pleasure of a more exalted kind. It is the pleasure which results from increased knowledge and understanding.

\section{BACKGROUND}

Every age has seen poets, and poetry in every age has drawn people towards its effects. It has seen various changes and various ups and downs. However, it cannot be denied that despite several changes, it has never lost its significance. Ted Hughes occupies a distinct place in English poetry. As a modern poet he always enjoys an envious reputation. His poetry seems to be compound of the various concepts given by several poets from time to time. Sometimes, it seems to resemble the symbolic poetry of Yeats while at other times it seems to resembling Eliots' poetry. However, it can be said for certain that despite a close resemblance to poetry of the several poets Hughes' poetry bears a stamp of originality in it. His poetry is a particular observation, an expression of his own.

Ted Hughes belongs to movement poets, particularly known as movement poet. The poetry of the movement poets was a reaction against the poetic trends of $1940 \mathrm{~s}$. Robert Conquest defines the aesthetic of the movement poetry in his introduction to the anthology New Lines where he tries to adumbrate the movement poets' attitude to life and art. "I believe the most important general point would be that it submits to no great system of theoretical constructs or agglomerations of unconscious commands. It is free from both mystical and logical compulsions and like modern philosophy - is empirical in attitude to all that comes"

The poetry of the 1950s was taking refuse in a kind of numbness. This numbness was a sheer evasion and not a way of coming to terms with the reality of its age, war and wanton death and destruction as its inevitable outcome. This sense of self-induced numbness has been reflected by Donald Davie in his 'Creon's Mouse': 'If too much daring brought (he thought) the war, when that was over nothing else would serve but no - one must be daring any more, a self-induced and stubborn loss of nerve.' Davie seems to be aware that these sophisticated scientific devices 
invented by human mind to cause Hiroshima and the gas chamber of Nazi concentration camps are but a manifestation of forces operating within the human psyche. Any evasion from examining these forces, any nonchalant pose in this regard cannot be a responsible poetic attitude.

The poetry of the movement exhibits all the systems of psychic illness. Contrary to conquest's claim that the poets who anthologized in New Lines were emulating the Augustans, the range of Augustan empire had narrowed down in them to a stage where Hughes's areas of experience, especially of the immediate past remained ignored. The urbane imagery of past poets and their tone of polite conversation were inadequate in the context of a post-Hiroshima, post-holocaust poetry. In their zeal to emulate the Augustans, the movement poets also showed an exaggerated concern with technique at times behaving as if the technique of medicine be more important than healing.

\section{HUGHES' POETRY}

The first poem written by Ted Hughes 'The Little Boys' and the Season' appeared in Granta in 1954 under the pseudonym Daniel Hearing. The very choice of a pseudonym indicated an attitudinal difference of the rest of the poetic community in $1950 \mathrm{~s}$. His pseudonym served perhaps as his individual poetic manifesto to mark the difference between him and the rest of his link in $1950 \mathrm{~s}$. His nom de plume was certainly to show his association with the Biblical Book of Daniel which is a Shamanistic apocalyptic poem written in a period of a people's spiritual crisis and forms a part of the Old Testament. Daniel is the chosen one who would provide his people with the means of spiritual renewal in pure Shamanistic terms. Daniel sees as his bounden duty to lead his people out of the spiritual crisis because the privilege of having seen the vision and having heard the aplitic voice has fallen on him. The choice of Hughes's nom de plume, although he relinquishes it later, indicates the similarity of intention between him and Daniel: to hear and proclaim a message of spiritual renewal in a decadent age.

One of the implications behind this choice of pseudonym was perhaps to revive imagination as a reliable mental faculty which has been declared inauthentic is a scientific society where everything needs to be corroborated by evidence. For Hughes and the Shaman imagination is the only agency of those supra rational insight which a poet needs for his own spiritual guidance as well as for his community. He has to lead a society which has become chronically sick as a result of the ban on imagination due to the inherent mistrust in its potential in a civilization steeped in scientificity. However, Ted Hughes does not stand alone in the tradition of English poetry in this regard. $\mathrm{He}$ is just a new bud on an old bough. Blake and the romantics had already anticipated him in terms of the mystic power that imagination confers on a poet. However, the difference lies in the fact that Blake came at the beginning of the scientific revolution whereas Hughes comes at a time which could be its end. Hence, the urgency gets augmented for Hughes. He tries to explore what the objective scientific perception of reality ignores: the mystic power of the inner world within man. Equipped with this power, "Its stride is wilderness of freedom. The world rolls under the long thrust of his heel.

This energy once C.G. Jung at the deeper levels of his psyche trapped would open new vistas of experience. In his essay Archaic Man says, "... every civilized human being, whatever his conscious development, is still an archaic man at the deeper levels of his psyche. Just as the human body connects us with the mammals and displays numerous relics of earlier revolutionary stages going back even further to the reptilian age, so the human psyche is likewise a product of evolution which, when followed up to the origin, shows countless archaic traits.. "Hughes wants this archaic man or the primal forces within the man's psyche to rise phoenix like breaking all the boundaries of the objective intelligence. It is this inner voice of the psyche which we hear in the poem, 'And the phoenix has come! : 'Its voice, Is the blade of desert a fishing of light its voice dangles glittering in the soft valley of dew.' The archaic man appears again in the 'The Jaguar' where the cage bar denies them their existence their enraged state reflects the turbulence of the inner world which has become chaotic and place fit for demons. It is, of course a part of our sense of Hughes's greatness that his poetry says something important. We have spoken of a 'consistent inspiration.' What is this inspiration? What is the main unifying perception in his work? In an interview with Egbert Fass, Hughes says, '"any form of violence - any form of vehement activity invokes the bigger energy, the elemental power circuits of the universe. Once the contact has been made - it becomes difficult to control. Something from beyond ordinary human activity enters. When the wise men know how to create rituals and dogma, the energy cannot be contained. When the old rituals and dogma have lost credit and disintegrated, and now new ones have been formed, the energy cannot be contained, and so its effect is destructive - and that is the position with us. And that is why force of any kind frightens our rationalist humanist style of outlook. In the old world God and divine power were invoked at any cost - life seemed worthless without them. In the present world we dare not invoke them - we wouldn't know how to use them or stop 
them destroying us. We have settled, for the minimum practical energy and illumination - anything bigger introduces problems, the demons get hold of it. That is the psychological stupidity, the ineptitude, of the rigidly rationalist outlook - it's a form of hubris, and we're paying the traditional price. If you refuse the energy, you are living a kind of death. If you accept energy it destroys you. What is the alternative? To accept the energy, and find methods of turning it to good, of keeping under control rituals, the machinery of religion. The old method is the only one.

Poet, like the witch doctor among primitive people, is a healer of the illness of a community. The same is true of Ted Hughes. It was the opinion that the western civilization is plagued with an incurable illness. It has its roots in the Judaea-Christian world view, in the reformed Christian ideas, and in the modern scientific advancements. He says that it is only a poet who can make people free from the horrible effects of the western civilization which knows nothing but hollow materialism. Ted Hughes's poetic endeavor over the past four and a decade has won him a distinguished place in the modern English poetry. His pre-eminent position in modern English poetry results from his literary stamina, intellectual strength and social awareness. Ted Hughes's poetic mission has always been to open our eyes to the power and mystery of the universe we inhabit.

Ted Hughes poetry reveals his disgust at the western civilization that is why, it is often propelled by a restless, and urgent energy to regain the lost contact with the mysterious power swamped inside our inner self. His vision is the vision of an observer who finds only immortality and detachment from Nature and animals. His agony as a modern man is reflected, in many of his poems Introducing his reading of his own poetry on the record, Ted Hughes says, 'I prefer poems to make an effect on being heard, and I don't think that really a case of them being simple because for instance Eliot's poems make a tremendous effect when you hear them, and when I first heard them they did, and when I was too young to understand very much about them they had an enormous effect on me, and this was an effect quite apart from anything that I'd call you know, understanding, or being able to explain them, or knowing what was going on. It's just some sort of charge and charm and series of operations that it works on you, and I think quite complicated poetry, such as Eliot's, can do this on you immediately.'

A careful reading between the lines of Hughes's poetry reveals the truth that he is a great poet skilled in his hands the language in the treatment of any theme is both familiar and different from anything we had thought possible. The charm of his poetry lies in its contents, but particularly in the language in which he shapes up. He is a prolific poet much more his poetic thoughts in the seventies than he seemed to be previously - and an uneven one, but his characteristic virtues can be seen in a remarkably large proportion in his work. He is a poet of our sense of Hughes's greatness that his poetry says something important. Hughes himself says in an interview - "my poems are not about violence but vitality. Animals are not violent; they are so much more completely controlled than men..?" Ted Hughes's reputation in English poetry rests upon his being a Nature poet, but Nature gets entirely a different shape in his poetry. His poetry is different from the poetry of Wordsworth and the poetry of the other celebrated poets who endeavored to delineate Nature in their poetry from time to time. However, it cannot be denied that Hughes's sensibility is pagan in the original sense. 'He is a haunter of the pagus, a heath-dweller, He moves by instinct in the thickets beyond the urbs; he is neither urban nor urbane. His poetry is a redolent of the lair as it is of the library.'

Hughes poetry is tremendously sensuous. The description of the things in his poetry reminds us of the sensuous poetry of Keats which essentially appeals to one while going through Hughes's or the other of our senses. While going Hughes' Poetry, on occasions it seems as if the object described was before us. The element of unconscious imparts a particular grace to his poetry. It is sensuous fetch, its redolence of blood and gland and grass and water, recalled English poetry in the fifties from a too suburban a version of the attention from the elemental; and the poems beat the hounds of a hidden England in streams and trees, on moors and in byres.

Ted Hughes began the $1960 \mathrm{~s}$ as an extremely accomplished and successful English poet; he ended the decade as a major force in European poetry. Through his association with the magazine Modern Poetry in Translation, which he co-edited from 1966 to 1971 with Daniel Weissbort, through essays, talks, and, above all, through his poems themselves, he helped to free English poetry as the 'universal language of understanding' during a period of sustained political tension. It was mainly through his personal contacts, and a measure of his literary stature and achievement, that in 1969 a magnificent selection of world poets were attracted to London to take part in a Poetry International, including such distinguished figures as W.H. Auden, Miroslav Holub of Czechoslovakia, Janos Pilinszky of Hungary, and Vasko Popa of Yugoslavia. 
Hughes poems record the epic journey of western man returning from exile; it is in this contact that Hughes began to explore the spiritual technique known as Shamanism. His poetry emphasizes restoration of cosmic balance and healing, and expresses itself in terms of journey of flight. It maps the way, or the gap between man and Nature. It realistically reveals the indifference to Nature, which has made him blind to enormous beauty of Nature for the sake of hollow materialism.

For Hughes poetry is not made out of thoughts or casual fancies. It is made out of experiences. His poetry is not the expression of casual fancies, but an emphatic expression of his experiences and of thought based on observation. His interaction with the people made him believe that the modern man is running after the civilization for the sake of social climbing and money. He has no eye to look at the beauty of Nature, no ear to hear the sweet sounds of Nature and no heart to enjoy the realistic sense.

However, if in one sense, Hughes poetry is antiautobiographical, it is, in a subjective sense, supremely and obsessively biographical, almost always functioning for the poet as a charm orcounter-magic against some problem that besets what the reader feels to be the poet's own lesser self, an ordinary waking self.

English poetry of the 1980s is still a romantic poetry, one that prefers individual insight to the conventional values of its society, and that tends to see itself as a privileged, indeed sovereign and unique, way of looking at life and judging it. Both aspects of these propositions are reflected in the poems of Ted Hughes. English poetry, from Chaucer to Larkin and beyond, has tended to give primacy to the human, the ordinary, the rational. Of course there have been large exceptions, most prominently Spenser and Milton; but Shakespeare, Dryden, Pope, Word worth, Tennyson, Browning, are figures one can properly cite as examples of this - to which one adds Skelton, Wyatt, Rochester, Crabbe, Cowper, Hardy and dozens of other poets who might seem unlikely allies. But here and there other names present themselves: Blake, Hopkins, and D.H. Lawrence. And it is here that Ted Hughes attaches himself to the argument.

The Hawk in the Rain' in The Hawk in the Rain, first called "The Hawk in the Storm' is based on a drama Scout Rock. This poem is one sustained and uncomfortable encounter between revealed forces. It is made evident in the hawk's 'still eye.' It is mere human eye which recognizes and feels intimidated by them for that has been brought into a momentary focus. The poem is apparently narrated by the man who sees with the human eye. The man is a rain drenched person who finds himself in the great job of a man-handled field. The speaker is at once attracted and repelled by the eye. He imagines himself as the terrified of hawk. And I, Bloodily grabbed dazed lastmoment-counting Morsel in the earth's mouth, strain towards the master - Fulcrum of violence where the hawk hangs still.

Here 'I' belongs to a dramatic fiction and is only indirectly identified with the poet's person. 'I' acts out momentarily the victim's role and commits a kind of suicide within the imagination. The final lines of the poem present a quite different perspective on the hawk. This poem is thus a transaction between perspectives and voices which are in tension. Sensual nature in this poem serves mainly as a set of counters for an inner drama which is the poet's real concern. Hughes did not write his first poem about an animal until sometime after he had started writing. 'Thought Fox' is the first of his animal poem. It is in many ways representative of what is to be found in his first two books. It is one of the earliest and best known poems - "I imagine this midnight moment's forest: Something else is alive beside the clock's loneliness And this blank page where my fingers move. Through the window I see no star: Something more near though deeper within darkness is entering the loneliness."

Hughes wrote that it is equally about the animal fox and also the process of poetic composition. The animal is no ordinary fox of the forest. It is a thought- fox, or sore precisely, the poet in his forest of the imagination is fused with Nature's fox. The fox functions as a metaphor of poetic creation.

In 'Thrushes', Hughes claims to put 'string beyond sense' into language. This languages either rises to the challenge of such extraordinary meanings as the thrush's stirring or it does not. For Hughes, figures of speech always have their primary meaning in what he refers to as 'audio conceptual', primary man, from which 'visual conceptual', man has grown estranged. For Hughes, successful figures of speech give the literal meaning, the real content of true experience. The surface meaning of metaphors thus belong to unreal man and his unreal experience, and are therefore, expandable as are our surface impression antidote to intellectual love of indolent

'Billet-Doux,' a hawkish predatory woman is an ideal antidote to the intellectual love of indolent procrastination. Such a woman is one- "who sees straight through bogyman, the crammed cafes, and the ten thousand books packed end to end, even my gross bulk.' Left to his own bookish device the intellectual is prey to the hawk of despair. Better that he should rise from his despair and encounter the creative force that resides in a woman. 'Loves a spoiled appetite for some delicacy-I am driven to your bed and four walls from bottomlessly breaking night. 
The word 'delicacy' as both fragility and a tasty moral contains the two attitudes men normally take to sex. Hughes adds a third view: sex as a physical salvation from intellectual despair. In his poem on intellectuals, Hughes attempts to put man in his place by exposing his pretentions. It is the connection of man that he can tame nature. Again Hughes dissents, believing that man is afraid of Nature.

Roars in a Ring' is a poem that begins with the trivial sound of a Christian Carol before being dramatically transformed into a tragic ballad: 'the air was new as a razor, the moor looked like moon, when they all went roaring homewards an hour before dawn.' Here the hour before dawn is for Hughes the time when humans sleep and animals come in to their own form. It is Christmas Eve and ground of drunken farmers celebrates the birth of Christ by drinking themselves into mindlessly hearty laughter (Hughes would not be Hughes if he did not see some cosmic significance in the furious despair crowning drinking of the farmers). For farmers the birth of Christ has not affected the fall of man, for on this Christmas Eve they still fall foul of their own nature, thud down to the ground.

Gaudete is a major advance in terms of Hughes's experiment with Shamanistic technique in the realm of poetry. The argument prepares the reader for the protagonist's entry into the visionary experience of the other world. Lumb, an Anglican clergyman, is abducted by spirits into the other world ostensibly to perform an act of healing which is to cure with a difficult child birth. The spirit makes his duplicate or changing cut of an Oak log to carry out this job in his world during his absence. The new Nicholas Lumb is to all appearances exactly the same as the real one but comes within his the elemental spirit of an Oak. Al though before being sent into this world the changing is subjected to horrific initiatory rites to take up the job of Reverend Lumb as perfectly as possible, he cannot suppress his fertility spirit and interpret the role of clergyman in a rather wooden way, He goes on copulating with the women of his parish under the excuse of performing fertility rites which would pro a massiah fathered by Lumb.

Life seems worthless without the energies Lumb releases; but once released, those energies cannot be controlled and so they destroy life. The women are in a trap. And so is Lumb. He cannot escape his own essential natura.All that latent energy that vegetable and animal procreative urge, challenged into a narrow man, can only express itself as overwhelming sexuality.

Besides these major themes - man in relation to the animals, the earth, the weather, the death and decay,
Hughes's poetry shows a new poetic trait, i.e. Shamanism, which appears as a prominent motif in Gaudete. An inkling of this trait can be traced in the very choice of his pseudonym Daniel. The Biblical Daniel is a Shaman who can interpret the king's dream because he is the chose one to understand revelation. Revelation breaks the barrier between heaven and Earth and the Shaman gets the pre-fall ability to talk to God. The Shaman can also understand the language of animal and grow intimate relationship with them. By virtue of these pre-fall attributes, the Shaman seeks answer to the spiritual questions for the sake of his clan or group.

Shamanism, thus, caters for Hughes's doctrine of energy, his love for the world nature, his metaphysic concern and his fascination with animals. It also helps him seek a remedy to the chronic sickness of the twentieth century society. Hughes's poetry is meant for a world that has lost its balance in spiritual terms. Hence his poetry intends to vividly portray the crisis, and at the same time, act as a healing force through its emphasis on the sagacity of the natural order and the mystery of the human psyche. Hughes employs the technique of Shamanism to explore the mystery of the human psyche. Hughes defines Shamanism in these words: 'Basically, it's the whole procedure and practice. Of becoming and performing as a witchdoctor, a medicine man, among primitive peoples. The individual is summoned by certain dreams. The same dreams all over the world, a spirit summons him ... usually an animal or a woman. If he refuses, he dies... or somebody near him-dies. If he accepts, he then prepares himself for the job ... it may take years. Usually he apprentices himself to some other Shaman, but the spirit may well teach him direct. Once fully fledged he can enter trance at will not go to the spirit world... he goes to get something badly needed, a cure, an answer, some sort of divine intervention in the community's affairs.

In Orghast, Hughes says that this inner true self, "All we know is that somehow or other the great, precious thing is missing. And the real distress of our world begins there. The luminous spirit (maybe he is a crowd of spirits), that takes account of everything and gives everything its meaning, is missing. Not missing, just incommunicado. But here and there, it may be, we hear it."

\section{CONCLUSION}

Ted Hughes is a gifted poet who has rich imagination, immortality and attachment with Nature and animals. His poetry is not the expression of casual fancies, but an emphatic expression of his experiences and of thought based on observation and his works help modern man recognize their own identity as both human and animals. It 
is human, of course, but it is also everything else that lives. When we hear it, we understand what a strange thing is living in this universe, and somewhere at the core of usstrange, beautiful, pathetic, terrible. Some animals and birds express this being pure and without effort, and then you hear the whole desolate, final actuality of existence in a voice or a tone.

\section{REFERENCES}

[1] Ted Hughes, 'The Jaguar,' The Hawk in the Rain (London: Faber and Faber, 1957)

[2] Ted Hughes, 'And the Phoenix has Come', Selected Poems (London: Faber and Faber, 1982)

[3] Quoted by Anthony Thwaite in A Critical Guide to British Poetry (London: Longman Group Limited, 1966)

[4] Kingsley Amis, 'Against Romanticism', New Lines (Manchester Manchester Univ. Press, 1967)

[5] Ted Hughes, in interview with Egbert Fass, Published in London Magazine, January, 1971.

[6] Quoted by Terry Gifford and Neil Roberts in Ted Hughes: A Critical study (London: Faber and Faber, 1981)

[7] Robert Conquest, 'Introduction', New Lines, Quoted in Keith Sagar (ed.), The Achievement of Ted Hughes (Manchester: Manchester Univ. Press, 1983)

[8] John Holloway, 'Warming', Quoted in Keith Sagar (ed) The Achievement of Ted Hughes (Manchester: Manchester Univ. Press, 1983)

[9] Quoted by Donald Davie in 'Ceron's Mouse', Here it is from Keith Sagar ed. The Achievement of Ted Hughes (Manchester: Manchester Univ. Press, 1983)

[10] C.G. Jung in 'Archaic Man,' Modern Man in Search of a Soul; Quoted in Keith Sagar (ed.) The Achievement of Ted Hughes (Manchester: Manchester Univ. Press, 1983)

[11] Ted Hughes, Quoted in Keith Sagar (ed.) The Achievement of Ted Hughes (Manchester: Manchester Univ. Press, 1983) 